\title{
TPCS/PBAT blown extruded films added with curcumin as a technological approach for active packaging materials
}

\author{
Sabrina Silva de Campos $^{\mathrm{a}}$, Anielle de Oliveira ${ }^{\mathrm{b}}$, Thaysa Fernandes Moya Moreira ${ }^{\mathrm{b}}$, \\ Tamires Barlati Vieira da Silva ${ }^{\mathrm{b}}$, Marcos Vieira da Silva ${ }^{\mathrm{a}}$, João A. Pinto ${ }^{\mathrm{c}, \mathrm{d}}$, Ana Paula Bilck ${ }^{\mathrm{e}}$, \\ Odinei Hess Gonçalves $^{\mathrm{b}, \mathrm{c}}$, Isabel Patrícia Fernandes ${ }^{\mathrm{c}, \mathrm{d}}$, Maria-Filomena Barreiro ${ }^{\mathrm{c}, \mathrm{d}}$, \\ Fabio Yamashita ${ }^{\mathrm{e}}$, Patricia Valderrama ${ }^{\mathrm{b}}$, Marianne Ayumi Shirai ${ }^{\mathrm{f}}$, Fernanda Vitória Leimann ${ }^{\mathrm{b}, \mathrm{d}, *}$ \\ ${ }^{a}$ Food Department (DALIM), Federal University of Technology-Paraná, Campus Campo Mourão (UTFPR-CM), Via Rosalina Maria Dos Santos, 1233, CEP 87301-899, \\ Campo Mourão, Paraná, Brazil \\ ${ }^{\mathrm{b}}$ Post-Graduation Program of Food Technology (PPGTA), Federal University of Technology-Paraná, Campus Campo Mourão (UTFPR-CM), Via Rosalina Maria Dos \\ Santos, 1233, CEP 87301-899, Campo Mourão, Paraná, Brazil \\ ${ }^{\mathrm{c}}$ Centro de Investigação de Montanha (CIMO), Instituto Politécnico de Bragança, Campus de Santa Apolónia, 5300-253, Bragança, Portugal \\ ${ }^{\mathrm{d}}$ Laboratory of Separation and Reaction Engineering - Laboratory of Catalysis and Materials (LSRE-LCM), Polytechnic Institute of Bragança, Campus Santa Apolónia, \\ 5301-253, Bragança, Portugal \\ ${ }^{\mathrm{e}}$ Food Science and Technology Department, Londrina State University (UEL), Rod. Celso Garcia Cid (PR 445), Km 380, P.O. Box: 10,011, CEP: 86057-970, Londrina, \\ $P R$, Brazil \\ ${ }^{\mathrm{f}}$ Food Department, Federal University of Technology-Paraná, Campus Londrina (UTFPR-LD), Avenida dos Pioneiros, 3131, CEP: 86036-370, Londrina, PR, Brazil
}

\section{A R T I C L E I N F O}

\section{Keywords:}

Biodegradable polymer

Bioactivity

Chia oil

Oxidative degradation

Antimicrobial

\begin{abstract}
A B S T R A C T
The development of active packaging is a relevant topic demanding the development of films with diverse properties to preserve specific foodstuff. The objective of this work was to obtain extruded TPCS/PBAT films containing curcumin and evaluate it as an active antimicrobial and antioxidant packaging to protect chia oil from oxidative degradation. Morphology, thermal, mechanical, antimicrobial, and antioxidant evaluation of the films were conducted to determine whether the presence of curcumin affected the film's properties. Infrared Spectroscopy indicated that curcumin addition affected the crosslinking reaction between citric acid and starch, which explains the changes in hydrophilicity and mechanical strength of the films. The incorporation of curcumin conferred antimicrobial activity against Gram-positive (Staphylococcus aureus) and Gram-negative (Pseudomonas aeruginosa and Escherichia coli) bacteria, as well as antioxidant activity. Films were tested as chia oil packaging, being verified that they successfully prevented oil degradation under accelerated stability test ( $60^{\circ} \mathrm{C}$ for 7 days), demonstrating the feasibility of using TPCS/PBAT biodegradable films containing curcumin to obtain active packaging materials.
\end{abstract}

\section{Introduction}

The main causes of deterioration of a wide variety of food products are lipid oxidation and microbial growth that occurs inside the packaging. The direct addition of antioxidants or antimicrobial agents to food formulations is often used. However, this procedure can lead to changes in sensory properties such as taste and food appearance. Furthermore, the amount of these additives is often not optimized, leading to unneeded high dosages in most cases. Active packaging materials emerge as an alternative to overcome these constraints (Baldino, Cardea, \& Reverchon, 2017). Biodegradable active packaging is one of the key issues of current food packaging research. To validate the ability of the film to act as an active packaging material some characteristics must be investigated, such as mechanical properties, antioxidant and antimicrobial activities and thermal stability (Siripatrawan \& Harte, 2010). Moreover, the addition of active compounds must not compromise film structure and other physical and mechanical properties (Jamshidian et al., 2012).

Starch is one of the natural polymers most studied to obtain biodegradable packaging, both by thermal processing and casting techniques. Thermoplastic Cassava Starch (TPCS) is formed through the gelatinization of native cassava starch by applying high-shear and

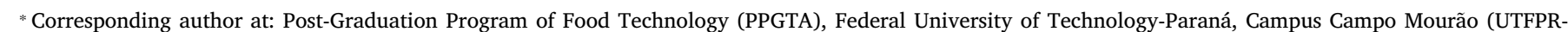
CM), Via Rosalina Maria Dos Santos, 1233, CEP 87301-899, Campo Mourão, Paraná, Brazil.

E-mail address: fernandaleimann@utfpr.edu.br (F.V. Leimann). 
pressure conditions (dry process), or by using excess of water ( $>90 \%$ wt) (Muller, González-Martínez, \& Chiralt, 2017). Unfortunately, the practical use of TPCS is hindered by its high water absorption capacity which leads to a decrease in barrier and mechanical properties (DilkesHoffman, Pratt, Lant, Levett, \& Laycock, 2018). Many studies have been conducted to evaluate the combination of thermoplastic starch from different sources with hydrophobic biodegradable polymers, such as poly(lactic acid) (Dilkes-Hoffman et al., 2018; Pizzoli et al., 2016), poly (butylene adipate-co-terephthalate) (Brandelero, Yamashita, \& Grossmann, 2010; González Seligra, Eloy Moura, Famá, Druzian, \& Goyanes, 2016; Olivato et al., 2017), and poly(caprolactone) (PCL) (Ishiaku, Pang, Lee, \& Ishak, 2002). Among the available range of biodegradable polymers, the poly(butylene adipate-co-terephthalate) (PBAT), an aliphatic-aromatic co-polyester, is an interesting option for biodegradable active packaging applications since it can be degraded in few weeks by naturally-occurring enzymes present in the environment. Hydrophilic/hydrophobic polymer blends such as starch-PBAT require the addition of compatibilizers to improve the adhesion and mechanical properties of the produced material, such as interfacial active organic acids (Garcia et al., 2014). These blends can be produced by a reactive extrusion in which organic acids promote starch crosslinking and hydrolyzation (Garcia et al., 2011; Olivato, Grossmann, Bilck, \& Yamashita, 2012; Olivato, Grossmann, Yamashita, Eiras, \& Pessan, 2012).

Natural antioxidants, such as essential oils and antioxidant extracts, have been applied to formulate active packaging materials. Curcumin is extracted from turmeric (Curcuma Longa L.) and has been extensively studied due to its relevant bioactive properties such as antioxidant and antimicrobial activity. Curcumin was added to gelatin films (Musso, Salgado, \& Mauri, 2017) and to cellulose acetate films (Baldino et al., 2017). However, the authors believe the application into reactive extruded films has not been investigated.

The objective of the present work was to evaluate the technological and functional aspects of TPCS/PBAT films containing curcumin added with a natural antioxidant/antimicrobial agent. For that, films were prepared by reactive blown extrusion using citric acid as a plasticizer/ compatibilizer. Antimicrobial, antioxidant, mechanical, thermal, microstructural and physical properties of the obtained films were also evaluated.

\section{Material and methods}

\subsection{Materials}

Films were produced using native cassava starch (thermoplastic cassava starch, TPCS) obtained from Indemil (Brazil), PBAT (poly(butylene adipate-co-terephthalate) - chemical structure presented in Fig. 1) supplied by BASF (Ecoflex ${ }^{\circledast}$, Ludwigshafen, Germany), and glycerol (Dinâmica, Brazil) as a plasticizer. Citric acid (plasticizer/<smiles>COc1cc(/C=C/C(=O)CC(=O)/C=C/c2ccc(O)c(OC)c2)ccc1O</smiles><smiles>CCOCCCCOC(=O)c1ccc(C(=O)OCCCCOC(=O)CCCCC(C)(C)C)cc1</smiles>

Fig. 1. Chemical structures of: (A) curcumin and (B) PBAT.
Table 1

TPS/PBAT blown extruded films formulations.

\begin{tabular}{llll}
\hline & BF & BFC1 & BFC2 \\
\hline Starch $(\mathrm{g})$ & 490 & 490 & 490 \\
Glycerol $(\mathrm{g})$ & 210 & 210 & 210 \\
PBAT $(\mathrm{g})$ & 300 & 300 & 300 \\
Citric acid $(\mathrm{g})$ & 0.3 & 0.3 & 0.3 \\
Curcumin $(\mathrm{g})$ & 0 & 5 & 7.5 \\
\hline
\end{tabular}

compatibilizer) and curcumin (chemical structure presented in Fig. 1) were supplied by Sigma-Aldrich (Steinheim, Germany). The FolinCiocalteu reagent, gallic acid, 2,2-diphenyl-1-picrylhydrazyl (DPPH), Trolox (6-hydroxy-2,5,7,8-tetramethychroman-105 2-carboxylic acid), ABTS (2,2'-azinobis [3-ethylbenzothiazoline-6-sulfonic acid] 106 diammonium salt), and potassium persulfate (dipotassium peroxydisulfate) were purchased from Sigma-Aldrich. Sodium carbonate and ethanol were of analytical grade.

\subsection{Production of the TPCS/PBAT films}

Films were produced according to the procedure described by Olivato, Grossmann, Bilck et al. (2012) and Olivato, Grossmann, Yamashita et al. (2012) with a few modifications (Table 1). The produced films consisted of the control formulation (BF), a film containing $0.5 \%$ wt of curcumin (BFC1), and a film containing $0.75 \%$ wt curcumin (BFC2). Films were produced in two stages. In the first, PBAT, glycerol, citric acid, starch, and curcumin, were manually mixed in this order, and processed using a laboratory single-screw extruder (model EL-25, BGM, Brazil) with a screw diameter (D) of $25 \mathrm{~mm}$ and a screw length of 28D. The barrel temperature profile was of $90 / 120 / 120 / 120^{\circ} \mathrm{C}$ from the feeding zone (zone 1) to the die zone (zone 4), respectively. The screw speed was of $35 \mathrm{rpm}$, using a die with six holes of $2 \mathrm{~mm}$ diameter. This first stage was necessary to properly mix the film constituents before the blowing stage. The obtained extruded cylindrical profiles and pellets were extruded to produce films with a barrel temperature profile of $90 / 120 / 125 / 125{ }^{\circ} \mathrm{C}$ in the four zones, and $130{ }^{\circ} \mathrm{C}$ in the $50 \mathrm{~mm}$ film-blowing die with internal air to form the film "bubble". The screw speed of $35 \mathrm{rpm}$ was maintained in this stage. It is worth noting that the temperature profile to minimize curcumin degradation inside the extruder since deterioration is expected to occur at high temperatures (Esatbeyoglu, Ulbrich, Rehberg, Rohn, \& Rimbach, 2015).

\subsection{Physical-chemical characterization}

For color analysis, the produced samples were evaluated regarding the parameters $\mathrm{L}^{*}, \mathrm{a}^{*}$, and $\mathrm{b}^{*}$ using a MiniScan EZ apparatus (HunterLab, USA) and by collecting 10 randomly chosen points in the film's surface. The apparent opacity of the films was determined according to the method described by Park and Zhao (2004) with a few modifications, using a UV-vis Spectrophotometer (Ocean Optics USB650UV, USA). Samples were cut into rectangles and thickness determined with a digital micrometer (Pantec, Brazil) with $0.001 \mathrm{~mm}$ resolution in 10 random points for each sample. Subsequently, the films to the inner wall of a quartz cuvette $(10 \mathrm{~mm}$ optical path) and analyzed at an absorbance of $600 \mathrm{~nm}$ using an empty cuvette as reference. The results were presented as the ratio between absorbance and film thickness $(\mathrm{mm})\left(\mathrm{Abs}_{600 \mathrm{~nm}} \cdot \mathrm{mm}^{-1}\right)$.

The moisture content of the original film was determined in order to use a dry-basis reference to measure the weight loss in water (WL) (Pizzoli et al., 2016). For that, films were weighted $\left(\mathrm{m}_{0}\right)$ in a circulation air oven for $24 \mathrm{~h}$ at $70{ }^{\circ} \mathrm{C}$, after which films were weighted $\left(\mathrm{m}_{1}\right)$ and the moisture content (M, \%) calculated using Equation (1).

$\mathrm{M}(\%)=100 .\left(\mathrm{m}_{0}-\mathrm{m}_{1}\right) / \mathrm{m}_{0}$

For the determination of the weight loss in water, dry samples 
$(2 \times 2 \mathrm{~cm})$ were weighted $\left(\mathrm{m}_{\mathrm{s} 1}\right)$, then immersed in distilled water $(250 \mathrm{~mL})$ using a flask under mild stirring for $24 \mathrm{~h}$ at $25^{\circ} \mathrm{C}$. Samples were then removed from the flasks, dried at $70{ }^{\circ} \mathrm{C}$ for $24 \mathrm{~h}$ and finally weighted $\left(\mathrm{m}_{\mathrm{s} 2}\right)$. The weight loss in water $(\mathrm{WL}, \%)$, in dry basis, was calculated according to Equation (2).

$\mathrm{WL}(\%)=100 .\left(\mathrm{m}_{\mathrm{s} 1}-\mathrm{m}_{\mathrm{s} 2}\right) / \mathrm{m}_{\mathrm{s} 1}$

Water contact angle was determined by deposition of one drop of water on the films surface (10 measurements for each determination) followed by image analysis with a goniometer (Hamé-Hart, USA).

A texture analyzer (Stable Micro Systems, model TA.TX2 +, England, $50 \mathrm{~kg}$ load cell) was used to determine the tensile properties (tensile strength (MPa), Young Modulus (MPa) and elongation at break (\%)) of the films based on the ASTM standard D882-91 (1996). For that, 10 samples of each formulation $(50 \mathrm{~mm}$ length and $20 \mathrm{~mm}$ width to fit to the tensile grips) were cut in the longitudinal direction and tests were carried out using the crosshead speed at $0.8 \mathrm{~mm} / \mathrm{s}$ and the initial distance between the grips equal to $30 \mathrm{~mm}$. Before testing, the samples were conditioned at $23 \pm 2{ }^{\circ} \mathrm{C}$ and relative humidity of $53 \pm 2 \%$ for $48 \mathrm{~h}$.

A scanning electron microscope (FEI, Quanta 200, USA) was used to examine the fractured surface of films. Previously to analysis, samples were submerged in liquid nitrogen, broken (cryogenic fracture) and gold-coated (Sputter Coater, BAL-TEC SCD 050, Germany). Samples were then stored at $25^{\circ} \mathrm{C}$ in a desiccator with $\mathrm{CaCl}_{2}(\approx 0 \% \mathrm{RH})$ for 3 days. Images were taken of the fragile fracture (500x magnification) and of the film's surface $(800 \times$ magnification $)$.

Fourier Transform Infrared analyses (FTIR) were carried out from 4000 to $500 \mathrm{~cm}^{-1}$ at $4 \mathrm{~cm}^{-1}$ resolution. A Perkin-Elmer Spectrum (model 1000 FT-IR, USA) with a Universal Attenuated Total Reflectance (UATR, ZnSe crystal) module was used. Samples were conditioned in a desiccator containing anhydrous calcium chloride $\left(\mathrm{CaCl}_{2}\right)$ for 10 days before the analysis.

The produced films were submitted to Differential Scanning Calorimetry (DSC, Perkin Elmer, 4000, Japan). Film samples previously kept in a desiccator with silica for 1 week, were weighed $(10 \mathrm{mg})$ into aluminum pans. The applied heating ramp was from 0 to $300{ }^{\circ} \mathrm{C}$ at a heating rate of $20^{\circ} \mathrm{C} / \mathrm{min}$ under nitrogen gas flow $\left(50 \mathrm{~mL} \cdot \mathrm{min}^{-1}\right)$ and the first scan was recorded. Thermogravimetric Analysis (TGA) was performed (TG 209-F3, Netzsch, Germany) using approximately $10 \mathrm{mg}$ of sample weighed into an alumina crucible. The heating ramp was from $20^{\circ} \mathrm{C}$ to $710^{\circ} \mathrm{C}$ at a heating rate of $10^{\circ} \mathrm{C} / \mathrm{min}$ using inert atmosphere (nitrogen, $20 \mathrm{~mL} / \mathrm{min}$ ).

\subsection{Antibacterial activity}

The antibacterial activity of the produced films was evaluated against the Gram negative bacteria Pseudomonas aeruginosa ATCC 9027 and Escherichia coli AATCC 10536, and the Gram positive bacteria Staphylococcus aureus ATCC 29213, selected as test microorganisms. The main objective was to study the presence/absence of antibacterial activity of the curcumin containing films. The tested samples comprised a suspension of pure curcumin in water $(0.5 \mathrm{mg} / \mathrm{mL}), \mathrm{BF}, \mathrm{BFC} 1$, and BFC2 films, and a kanamycin solution $(0.5 \mathrm{mg} / \mathrm{mL})$ as positive control. The applied method was based on the Kirby-Bauer method and on the ASTM E2149-01 standard. Briefly, bacteria inoculum was prepared by aseptically transferring 4 isolated colonies to nutrient broth, being incubated during $24 \mathrm{~h}$ at $37^{\circ} \mathrm{C}$. The inoculum was diluted to 0.5 McFarland turbidity standard (corresponding to a concentration of $1.5-3.0 \times 10^{8} \mathrm{CFU} / \mathrm{mL}$ ) using sterilized Ringer solution. The concentration of the bacteria dilution was controlled by spectrophotometry by measuring the absorbance at $625 \mathrm{~nm}$. Then, the bacteria solution was inoculated in Mueller Hinton Agar plates using a sterilized swab and the inoculated plates were left to dry for a short period of time. After that, for the curcumin and kanamycin solutions (liquid samples), a hole with a diameter of $7 \mathrm{~mm}$ was made in the agar in them center of the plate and $100 \mu \mathrm{L}$ of the curcumin and kanamycin solutions (liquid samples). For the films, samples with $7.0 \mathrm{~mm}$ diameter were cut and placed at the center of the plate. All conditions were prepared in duplicate and incubated at $37^{\circ} \mathrm{C}$ during $24 \mathrm{~h}$. After this, the diameter of the inhibition zone was measured and the incubation maintained for further 4 days ( $96 \mathrm{~h}$ ) in order to evaluate the possible growth of the inhibition zone caused by curcumin diffusion.

\subsection{Antioxidant activity of the curcumin-loaded films}

Antioxidant activity assays (DPPH and ABTS) of the produced films were performed following an extraction procedure according to the method described by De Araújo et al. (2015). Briefly, ethanol (30 mL) was added to the film sample $(1.5 \mathrm{~g})$, and the mixture homogenized using an Ultra-Turrax apparatus (T25, Ika, Germany) at 16,000 rpm for $5 \mathrm{~min}$, then at $6000 \mathrm{rpm}$ for $15 \mathrm{~min}$. The obtained mixture was centrifuged (NT825 Nova Técnica, Brazil) at $6000 \mathrm{rpm}$ for $15 \mathrm{~min}$ and the supernatant collected. Extraction was repeated twice by adding ethanol $(30 \mathrm{~mL})$ to the centrifuged precipitate and the three resulting ethanol fractions were stored at $-20^{\circ} \mathrm{C}$ until analysis.

ABTS assay was based on the method of Arnao, Cano, and Acosta (2001), as adapted by Thaipong, Boonprakob, Crosby, CisnerosZevallos, and Hawkins Byrne (2006). First, a stock solution was prepared from equal volumes of $7.4 \mathrm{mM}$ ABTS and $2.6 \mathrm{mM}$ sodium persulfate aqueous solutions. The stock solution was kept in the dark for $12 \mathrm{~h}$ to allow the formation of the ABTS radical (ABTS ${ }^{\circ}+$ ), then diluted with methanol until an absorbance of $1.100 \pm 0.010$ at $734 \mathrm{~nm}$ was reached (Ocean Optics, Red Tide USB650 Fiber Optic Spectrometer, USA) to obtain the working solution. $2.85 \mathrm{~mL}$ of the working solution was added to $150 \mu \mathrm{L}$ of the extract (or $150 \mu \mathrm{L}$ ethanol as the control) in test tubes. After homogenization, solutions were stored in the dark for $2 \mathrm{~h}$ and the absorbance at $734 \mathrm{~nm}$ was determined. Quantification was carried out using a previously obtained Trolox calibration curve, and expressed as $\mu \mathrm{mol}$ of Trolox equivalent (TE) per $100 \mathrm{~g}$ of film $\left(\mu \mathrm{mol}_{\mathrm{TE}} /\right.$ $100 g_{\text {film }}$ ) and all samples were analyzed in triplicate.

Procedure described by Mensor et al. (2001) was used in the DPPH assay with minor modifications. Briefly, $2.5 \mathrm{~mL}$ of the extract was mixed with $1 \mathrm{~mL}$ of $0.3 \mathrm{mM}$ DPPH methanol solution (or pure methanol as the control) in a test tube. After $30 \mathrm{~min}$ in the dark, the absorbance was determined at $518 \mathrm{~nm}$. All samples were analyzed in triplicate.

The antioxidant capacity was calculated using a Trolox standard curve and the results were expressed as $\mu \mathrm{mol}_{\mathrm{TE}} / 100 \mathrm{~g}_{\text {film sample. }}$.

\subsection{Oxidative stability of packaged chia oil}

As a proof-of-concept, chia oil was packed on the produced packaging materials (BFC1 and $\mathrm{BF}$ ), and its oxidation state was evaluated under accelerated oxidative stability conditions $\left(60^{\circ} \mathrm{C}, 7\right.$ days) using Ultraviolet-Visible (UV-vis) Spectroscopy coupled to chemometry. The procedure, in duplicate, followed the one proposed by Andreo and Jorge (2007), with modifications. Briefly, test tubes with the inner part covered by the films (BFC1 and BF) were filled with $5 \mathrm{~mL}$ of chia oil. In addition, $5 \mathrm{~mL}$ of chia oil were added to test tubes without any film coating (control). The test tubes were placed in an oven (Cienlab, Campinas, SP, Brasil) at $60{ }^{\circ} \mathrm{C}$ for 7 days. Oil absorbance was measured (Ocean Optics model USB-650-UV-VIS) from 300 to $540 \mathrm{~nm}$ at $1 \mathrm{~nm}$ resolution. Formation of the oxidation products was evaluated by the chemometric curve resolution method by Multivariate Curve Resolution with Alternating Least Squares (MCR-ALS), as described by Gonçalves, Março, and Valderrama (2014). MCR-ALS are able to resolve the signals corresponding to the various oil constituents without resorting to physical separation procedures. This method also allow to verify the presence of tocopherol in the oil samples (Valderrama, Março, Locquet, Ammari, \& Rutledge, 2011). 
Table 2

Antioxidant activity (DPPH and ABTS), color parameters ( $\mathrm{L}^{*}, \mathrm{a}^{*}$ and $\mathrm{b}^{*}$ ), opacity, weight loss in water $(\mathrm{WL})$, water contact angle $\left(\theta_{\mathrm{H} 2 \mathrm{O}}\right)$ and films thickness determined for TPS/PBAT films: control formulation (BF), film added with $0.5 \%$ of curcumin (BFC1) and film added with $0.75 \%$ of curcumin (BFC2).

\begin{tabular}{|c|c|c|c|}
\hline & $\mathrm{BF}$ & BFC1 & $\mathrm{BFC} 2$ \\
\hline \multicolumn{4}{|l|}{ Antioxidant Activity } \\
\hline $\mathrm{DPPH}\left(\mu \mathrm{mol}_{\mathrm{TE}} / 100 \mathrm{~g}_{\text {film }}\right)$ & $\begin{array}{l}160.93^{\mathrm{a}} \pm \\
15.65\end{array}$ & $\begin{array}{l}1605.25^{b} \pm \\
48.13\end{array}$ & $\begin{array}{l}2290.69^{c} \pm \\
52.10\end{array}$ \\
\hline $\operatorname{ABTS}\left(\mu \mathrm{mol}_{\mathrm{TE}} / 100 \mathrm{~g}_{\mathrm{film}}\right)$ & $\mathrm{nd}^{*}$ & $\begin{array}{l}2815.77^{\mathrm{a}} \pm \\
15.25\end{array}$ & $\begin{array}{l}5287.58^{\mathrm{b}} \pm \\
204.48\end{array}$ \\
\hline \multicolumn{4}{|l|}{ Color Parameters } \\
\hline $\mathrm{L}^{*}$ & $79.31^{c} \pm 2.52$ & $70.80^{\mathrm{b}} \pm 4.24$ & $63.99^{\mathrm{a}} \pm 3.17$ \\
\hline$a^{*}$ & $-3.96^{\mathrm{a}} \pm 1.9$ & $9.94^{b} \pm 2.78$ & $14.32^{c} \pm 2.71$ \\
\hline$b^{*}$ & $9.04^{\mathrm{a}} \pm 3.46$ & $64.46^{b} \pm 6.46$ & $74.36^{c} \pm 5.22$ \\
\hline Opacity $\left(\mathrm{Abs}_{600 \mathrm{~nm}} \cdot \mathrm{mm}^{-1}\right)$ & $5.10^{\mathrm{a}} \pm 0.24$ & $4.81^{\mathrm{a}} \pm 0.72$ & $13.64^{b} \pm 0.52$ \\
\hline \multicolumn{4}{|l|}{ Physical characterization } \\
\hline WL $(\%)$ & $20.45^{\mathrm{a}} \pm 0.15$ & $24.14^{\mathrm{b}} \pm 0.28$ & $24.06^{\mathrm{b}} \pm 0.18$ \\
\hline$\theta_{\mathrm{H} 2 \mathrm{O}}\left({ }^{\circ}\right)$ & $68.56^{\mathrm{b}} \pm 1.41$ & $63.21^{\mathrm{a}} \pm 1.57$ & $60.17^{\mathrm{a}} \pm 0.39$ \\
\hline Thickness $(\mu \mathrm{m})$ & $0.35^{\mathrm{a}} \pm 0.10$ & $0.29^{\mathrm{a}} \pm 0.04$ & $0.31^{\mathrm{a}} \pm 0.06$ \\
\hline
\end{tabular}

* nd - not detected; Results expressed as mean \pm standard deviation; ${ }^{\text {a,b,c }}$ different letters in the same row indicate significant difference between the treatments by Tukey's test $(\mathrm{p}<0.05)$.

\subsection{Statistical analysis}

The obtained results were evaluated using analysis of variance (ANOVA), and averages compared using Tukey's test at a 5\% significance level $(\mathrm{p}<0.05)$ using the software Statistica 7.0 (Statsoft, USA).

\section{Results and discussion}

\subsection{Antioxidant and antibacterial activity, color and physical characteristics}

Table 2 shows the results obtained for the antioxidant activity of the produced while Table 3 presents the results obtained for the antibacterial activity.

There was a significant increase $(\mathrm{p}<0.05)$ in the antioxidant capacity measured by DPPH from the control sample (BF) to the films containing curcumin, which was 10- and 14-fold superior for the films produced with curcumin at $0.5 \%$ (BFC1) and $0.75 \%$ (BFC2), respectively. The control film also presented antioxidant activity, probably due to the presence of citric acid (Hraš, Hadolin, Knez, \& Bauman, 2000). The films containing curcumin presented increased antioxidant

Table 3

Antibacterial activity of the films (mean values of the inhibition halo diameter $(\mathrm{cm})$ obtained on the agar diffusion test).

\begin{tabular}{|c|c|c|c|}
\hline & S. aureus & P. aeruginosa & E. coli \\
\hline & \multicolumn{3}{|c|}{ Incubation: 24 hours } \\
\hline Curcumin & $1.00^{c} \pm 0.00$ & $1.00^{c} \pm 0.00$ & $1.00^{c} \pm 0.00$ \\
\hline Kanamycin & $3.00^{\mathrm{d}} \pm 0.00$ & $1.00^{c} \pm 0.00$ & $3.00^{\mathrm{d}} \pm 0.00$ \\
\hline BF & $0.70^{\mathrm{a}} \pm 0.00$ & $0.70^{\mathrm{a}} \pm 0.00$ & $0.70^{\mathrm{a}} \pm 0.00$ \\
\hline BFC1 & $0.80^{\mathrm{b}} \pm 0.00$ & $0.85^{\mathrm{b}} \pm 0.07$ & $0.85^{\mathrm{b}} \pm 0.07$ \\
\hline \multirow[t]{2}{*}{ BFC2 } & ${ }^{\mathrm{b}} 0.70 \pm 0.00$ & $0.85^{\mathrm{b}} \pm 0.07$ & $0.80^{\mathrm{b}} \pm 0.00$ \\
\hline & \multicolumn{3}{|c|}{ Incubation: 96 hours } \\
\hline Curcumin & $1.00^{c} \pm 0.00$ & $1.00^{b, c} \pm 0.00$ & $1.00^{\mathrm{b}} \pm 0.00$ \\
\hline Kanamycin & $2.50^{\mathrm{b}} \pm 0.00$ & $1.00^{\mathrm{b}, \mathrm{c}} \pm 0.00$ & $2.50^{c} \pm 0.00$ \\
\hline BF & $0.70^{\mathrm{a}} \pm 0.00$ & $0.80^{\mathrm{a}} \pm 0.00$ & $0.95^{\mathrm{a}, \mathrm{b}} \pm 0.07$ \\
\hline BFC1 & $0.80^{\mathrm{b}} \pm 0.00$ & $0.85^{\mathrm{a}} \pm 0.07$ & $0.85^{\mathrm{a}} \pm 0.07$ \\
\hline BFC2 & $0.70^{\mathrm{a}} \pm 0.00$ & $1.10^{\mathrm{c}} \pm 0.28$ & $0.90^{\mathrm{a}, \mathrm{b}} \pm 0.00$ \\
\hline
\end{tabular}

$\overline{\mathrm{a}, \mathrm{b}, \mathrm{c}, \mathrm{d}}$ different letters in the same column indicate significant difference between the treatments by Tukey's test $(\mathrm{p}<0.05)$. capacity $(\mathrm{p}<0.05)$ despite remaining undetected in the ABTS assay. da Silva-Buzanello et al. (2016) evaluated the pure curcumin ABTS scavenging capacity and obtained a result of $824 \mu \mathrm{M}_{\mathrm{TE}} / \mathrm{g}_{\text {curcumin. }}$. The results demonstrated that the antioxidant activity of curcumin was preserved even when it was subjected to the high temperatures and shear rate during extrusion.

The results obtained for the color evaluation of the films as a function of their composition are presented in Table 2. The control sample presented a whitish appearance, typical of TPCS/PBAT films obtained by extrusion, and the highest luminosity results $\left(L^{*}=79.31\right)$. The increase of curcumin content in the film led to a decrease in the luminosity parameter and a significant increase $(p<0.05)$ in the $b^{*}$ parameter, which indicates the tendency to yellow. A tendency to green (negative a* values) was also observed for the control sample while film samples added with curcumin presented a tendency to red (positive a* values). The control film and the film with the lowest curcumin content did not differ significantly in opacity.

Weight loss in water (WL, Table 2) ranged from 20.45 to $24.14 \%$, values inferior to the ones reported by Olivato, Grossmann, Bilck et al. (2012) with TPCS/PBAT films added with organic acids as additives, which can be attributed to the lower concentration of TPCS in the formulation. WL showed a significant increase $(\mathrm{p}<0.05)$ with the increase of curcumin concentration, suggesting a rise in hydrophilicity caused by curcumin. It is also worth noting the reduction in the contact angle with water (Table 2) which corroborates the increase in hydrophilicity caused by curcumin. Film thickness was not affected by the addition of curcumin.

Analyzing the results presented in Table 3 , no bacterial inhibition was detected in the control film after $24 \mathrm{~h}$ in incubation and a $1.0 \mathrm{~cm}$ halo was formed in the case of powder curcumin for all tested bacteria. The antibacterial property of curcumin is explained by its ability to influence proliferation, inhibition, and killing mechanisms (Luo, Varaprasad, Reddy, Rajulu, \& Zhang, 2012). Inhibition halos were detected for all the three bacteria tested in the films containing curcumin, with $P$. aureginosa presenting the widest one $(0.85 \mathrm{~cm})$. After 4 days, an increase was verified in the inhibition halo against the Gram-negative bacteria, especially for $E$. coli. This can be attributed to the leaching and diffusion of the citric acid contained in the film formulation, which also presents antibacterial capacity, particularly against gram-negative bacteria (In, Kim, Kim, \& Oh, 2013). For the BFC2 sample $(0.75 \%$ wt curcumin), an increase in the inhibition halo was detected for both tested Gram negative bacteria, which could be attributed to curcumin diffusion and release, as well as to citric acid leaching. For the BFC1 sample, the inhibition halo was maintained in both cases, indicating that, from the antibacterial perspective, the use of a curcumin content of $0.75 \%$ wt is more advantageous. These results are in agreement with the ones obtained by Luo et al. (2012), who studied cellulose films containing curcumin, also finding an increase in the inhibition halo of E. coli. Looking at the evolution of the $S$. aureus inhibition halo for BFC1 and BFC2 samples from 24 to $96 \mathrm{~h}$, a decrease in the diameter from 0.8 to $0.7 \mathrm{~cm}$ was noticed for the BFC2 sample, and non for the BFC1 sample. This was unexpected since the BFC2 sample has a higher content of curcumin. This is possibly due to the lack of adhesion of the BFC2 film, which could lead to a lower curcumin diffusion and a reduced inhibition halo. It is worth noting that, at the end of the test, the films were removed from the plates and no bacterial growth was identified under them. The overall results indicated a satisfactory antibacterial performance of the TPCS/PBAT films containing curcumin, especially for the formulation BFC2.

\subsection{Fourier transform infrared spectroscopy (FTIR)}

Fig. 2 shows the FTIR spectra of the produced film samples and of pure curcumin.

The characteristic curcumin bands at $1602 \mathrm{~cm}^{-1}$ (aromatic ring $\mathrm{C}-\mathrm{C}$ bonds) and $1506 \mathrm{~cm}^{-1}(\mathrm{C}=\mathrm{C})$ (Lemes et al., 2017) were visible in 


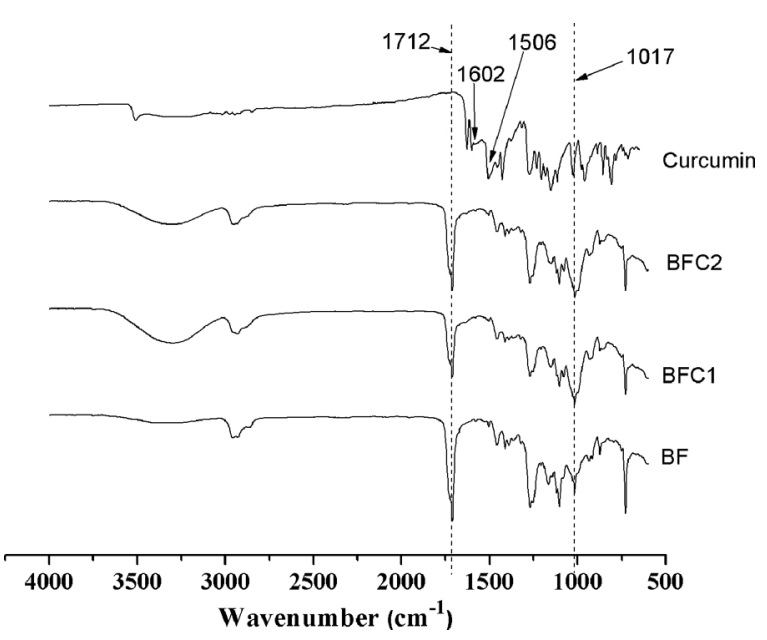

Fig. 2. FTIR-ATR spectra: curcumin; BFC2 (TPCS $\backslash$ PBAT film with $0.75 \%$ wt of curcumin); BFC1 (TPS \PBAT film with $0.75 \%$ wt of curcumin); BF (TPCS $\backslash$ PBAT control film).

the pure curcumin spectra with large intensity, and were attenuated in the films spectra. The TPCS/PBAT $\mathrm{C}=\mathrm{O}$ ester group (at $1712 \mathrm{~cm}^{-1}$ ) (Garcia et al., 2011) presented lower intensity in the curcumin loaded films when compared to the control film. This may be related to the interference of curcumin on the starch esterification reaction with citric acid (Shi et al., 2007). Another point is the lower intensity of the band located at $1017 \mathrm{~cm}^{-1}$ (assigned to the $\mathrm{C}-\mathrm{O}-\mathrm{C}$ group) in comparison with the control sample (BF). According to Shi et al. (2007), this reduction indicates a higher acid hydrolysis from glycosidic bonds of starch by citric acid. This also indicates that curcumin inhibited citric acid reaction with starch molecules, probably due to the competition with the association of curcumin with hydroxyl groups to form hydrogen bonds (Wu, Chen, Li, \& Li, 2009).

In the spectra of BFC1 and BFC2 samples, a broad band due to hydrogen bonded hydroxyl groups $(\mathrm{O}-\mathrm{H})$ appears centered at approximately $3300 \mathrm{~cm}^{-1}$, being attributed to the complex vibrational stretches associated with free, inter and intramolecular bonded hydroxyl groups. These facts may also be related with the reduction of the esterification reaction between starch and citric acid, explaining the achieved higher solubility results (Table 2) observed with these samples. In fact, a lower esterification level of the starch may lead to films with a higher solubility in water.

\subsection{Thermal properties}

In Fig. 3 the acquired DSC thermograms of the produced films, as well as, of pure curcumin are presented. Fig. 4 shows the results obtained by TGA and DTG analysis and Table 4 presents the degradation temperatures of TPCS and PBAT (peak's onset and maximum), as well as the respective weight loss.

Since PBAT is a block copolymer, it is composed by repetition units of butylene adipate (BA) and butylene terephthalate (BT), as can be observed in the molecular structure presented in Fig. 1. The molecule's portions composed by BA are called soft segments, due to its aliphatic structure that allows an increased mobility. On the other hand, the segments composed by the repetition of BT monomeric units, are called rigid segments, due to the aromatic terephthalate (Nakamura, Abe, Doi, Kuwabara, \& Gan, 2002). Because of the incompatibility of hard and soft segments, the material often undergoes microphase separation, clustering into hard and soft domains (Korodi \& Marcu, 1983).

It is possible to observe the presence of the crystalline melting temperature $(\mathrm{Tm})$ related to the PBAT butylene adipate (BA) segments at $50{ }^{\circ} \mathrm{C}, 49^{\circ} \mathrm{C}$ and $52{ }^{\circ} \mathrm{C}$ for the control (BF), BFC1 and BFC2 respectively (González Seligra et al., 2016). A second Tm transition, related to the rigid butylene terephthalate (BT) segments, was registered at $90^{\circ} \mathrm{C}$. For the BFC1 and BFC2 samples this transition shifted to $84^{\circ} \mathrm{C}$ which
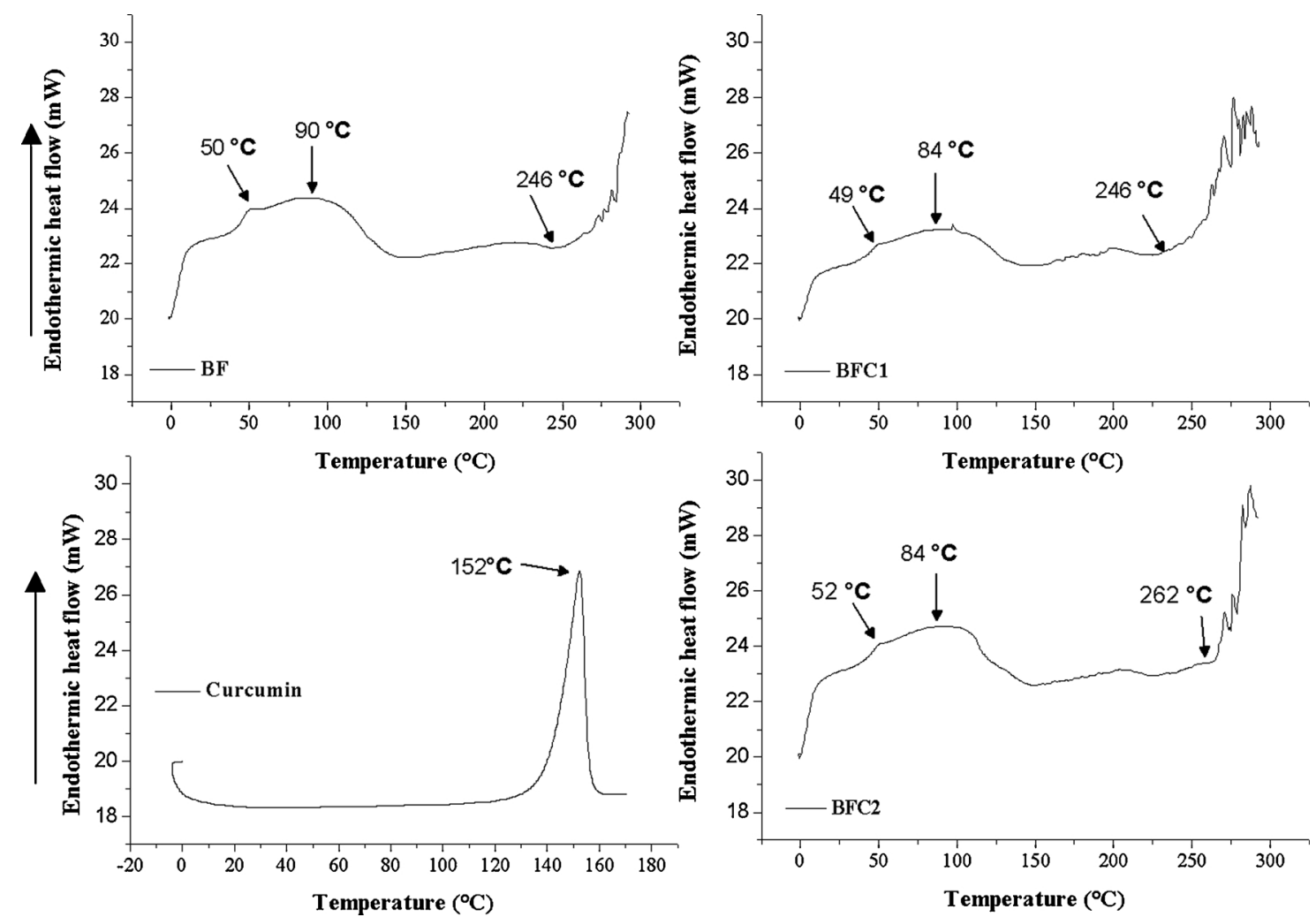

Fig. 3. DSC thermograms of curcumin; BFC2 (TPCS \PBAT film with $0.75 \%$ wt of curcumin); BFC1 (TPS $\backslash$ PBAT film with $0.75 \%$ wt of curcumin); BF (TPCS $\backslash$ PBAT control film). 

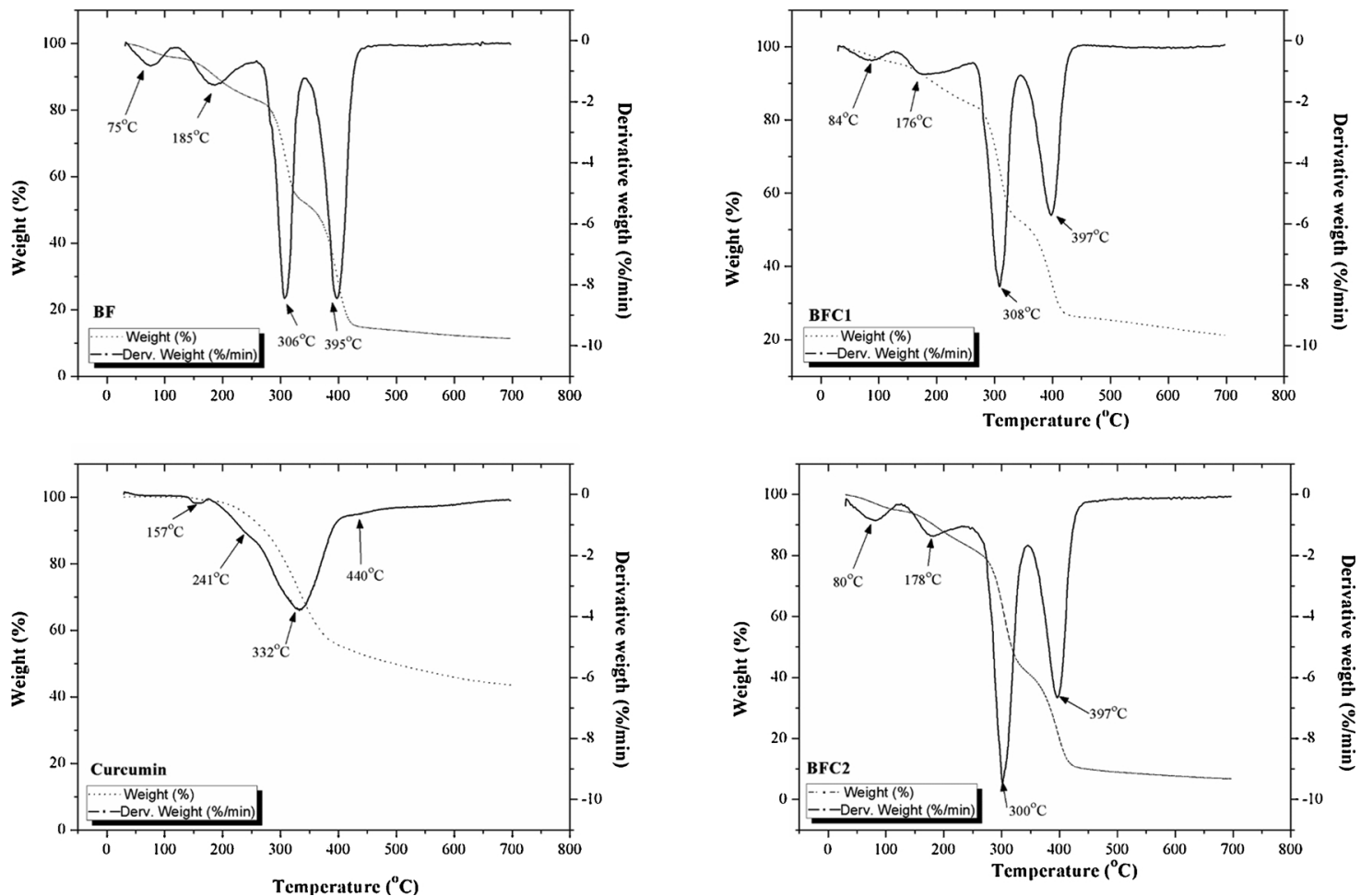

Fig. 4. TGA thermograms of curcumin; BFC2 (TPCS \PBAT film with $0.75 \%$ wt of curcumin); BFC1 (TPS \PBAT film with $0.75 \%$ wt of curcumin); BF (TPCS \PBAT control film).

Table 4

Degradation temperatures of TPS and PBAT (peak's onset and maximum), and weight loss at degradation peaks of TPS and PBAT.

\begin{tabular}{|c|c|c|c|c|c|c|}
\hline \multirow[t]{2}{*}{$\begin{array}{l}\text { Film } \\
\text { Formulation }\end{array}$} & \multirow[t]{2}{*}{$\begin{array}{l}\mathrm{T}_{\text {TPS }} \\
\text { onset }\left({ }^{\circ} \mathrm{C}\right)\end{array}$} & \multirow[t]{2}{*}{$\begin{array}{l}\mathrm{T}_{\mathrm{TPS}} \\
\max \left({ }^{\circ} \mathrm{C}\right)\end{array}$} & \multirow[t]{2}{*}{$\begin{array}{l}\mathrm{T}_{\text {PBAT }} \\
\text { onset }\left({ }^{\circ} \mathrm{C}\right)\end{array}$} & \multirow[t]{2}{*}{$\begin{array}{l}\mathrm{T}_{\mathrm{PBAT}} \\
\max \left({ }^{\circ} \mathrm{C}\right)\end{array}$} & \multicolumn{2}{|c|}{$\begin{array}{l}\text { Weight loss in } \\
\text { degradation (\%) }\end{array}$} \\
\hline & & & & & TPS & PBAT \\
\hline $\mathrm{BF}$ & 260 & 306 & 341 & 395 & 31.0 & 36.7 \\
\hline BFC1 & 261 & 308 & 344 & 397 & 30.0 & 31.0 \\
\hline $\mathrm{BFC} 2$ & 241 & 300 & 346 & 397 & 42.4 & 31.2 \\
\hline
\end{tabular}

Table 5

Mechanical propeties in terms of Young's Modulus (YM), tensile strenght (TS) and elongation at break (E) of the produced TPS/PBAT films: control formulation (BF), film added with $0.5 \%$ of curcumin (BFC1) and film added with $0.75 \%$ of curcumin (BFC2).

\begin{tabular}{llll}
\hline Film Formulation & YM (MPa) & TS (MPa) & E (\%) \\
\hline BF & $24.03^{\mathrm{a}} \pm 3.26$ & $4.41^{\mathrm{a}} \pm 0.58$ & $27.86^{\mathrm{a}} \pm 5.89$ \\
BFC1 & $23.04^{\mathrm{a}} \pm 1.09$ & $4.10^{\mathrm{a}} \pm 0.11$ & $28.73^{\mathrm{a}} \pm 2.08$ \\
BFC2 & $33.17^{\mathrm{b}} \pm 1.96$ & $6.66^{\mathrm{b}} \pm 0.33$ & $39.98^{\mathrm{b}} \pm 3.82$ \\
\hline
\end{tabular}

Results expressed as mean \pm standard deviation; ${ }^{\text {a,b,c }}$ different letters in the same column indicate significant difference between the treatments by Tukey's test $(\mathrm{p}<0.05)$.

could be due to the increase in the disorder of the molecular arrangements caused by the presence of curcumin into the polymers microstructure. PBAT presented a thermal degradation in the range of 355-440 ${ }^{\circ} \mathrm{C}$ (González Seligra et al., 2016), which is compatible with the results presented in Table 4 and Fig. 4. A slightly lower onset degradation temperature for PBAT was detected with BF sample.

Film degradation occurs in four steps. The first two are related to moisture loss and glycerol degradation, respectively. The third is related to TPCS degradation, and the fourth, with PBAT degradation (Lendvai, Apostolov, \& Karger-Kocsis, 2017). According to Liu et al.
(2013), starch thermal degradation occurs in a temperature range of $160-380^{\circ} \mathrm{C}$, depending on the botanical origin and the amylose/amylopectin ratio. The results summarized in Table 4 demonstrated that the maximum temperature for TPCS degradation $\left(161^{\circ} \mathrm{C}\right)$ is within this range. The onset temperature of TPCS degradation was higher in the BF and BFC1 samples, followed by the BFC2. On the other hand, the weight loss temperature range associated with TPCS degradation was higher for the BFC2 sample. These results are a consequence of the higher thermal degradation stability associated to the crosslinked starch.

\subsection{Mechanical properties and morphology}

Table 5 presents the results obtained for the evaluated mechanical properties (Young's Modulus, tensile strength and elongation at break) of the produced films.

The addition of $0.5 \%$ wt curcumin (BFC1) did not affect ( $\mathrm{p}>0.05$ ) the mechanical properties. On the other hand, the increase in curcumin content to $0.75 \% w t$ led to a significant increase $(p<0.05)$ for all the evaluated mechanical properties. This sample was more ductile when compared to the control and BFC1 formulations. According to Garcia et al. (2011), the crosslinking of starch by the action of citric acid decreases both tensile strength and elongation at break of TPCS/PBAT materials. Better results were obtained since this reaction was hindered due to the presence of curcumin. Furthermore, the change in mechanical properties may not be associated with a plasticizing effect since this behavior was undetected by DSC, and also no improvement in compatibilization could be detected by comparing the glass transition temperature of the individual materials and the produced blends.

Fig. 5 shows the SEM images of the films' surface and the fragile fractures.

No appreciable modification in microstructure was detected as a function of the addition of curcumin. On the other hand, the surface images of BFC1 and BFC2 films show a higher amount of non-gelatinized starch granules. As previously discussed, curcumin restricted the action of citric acid as plasticizer or compatibilizer, hindering the 


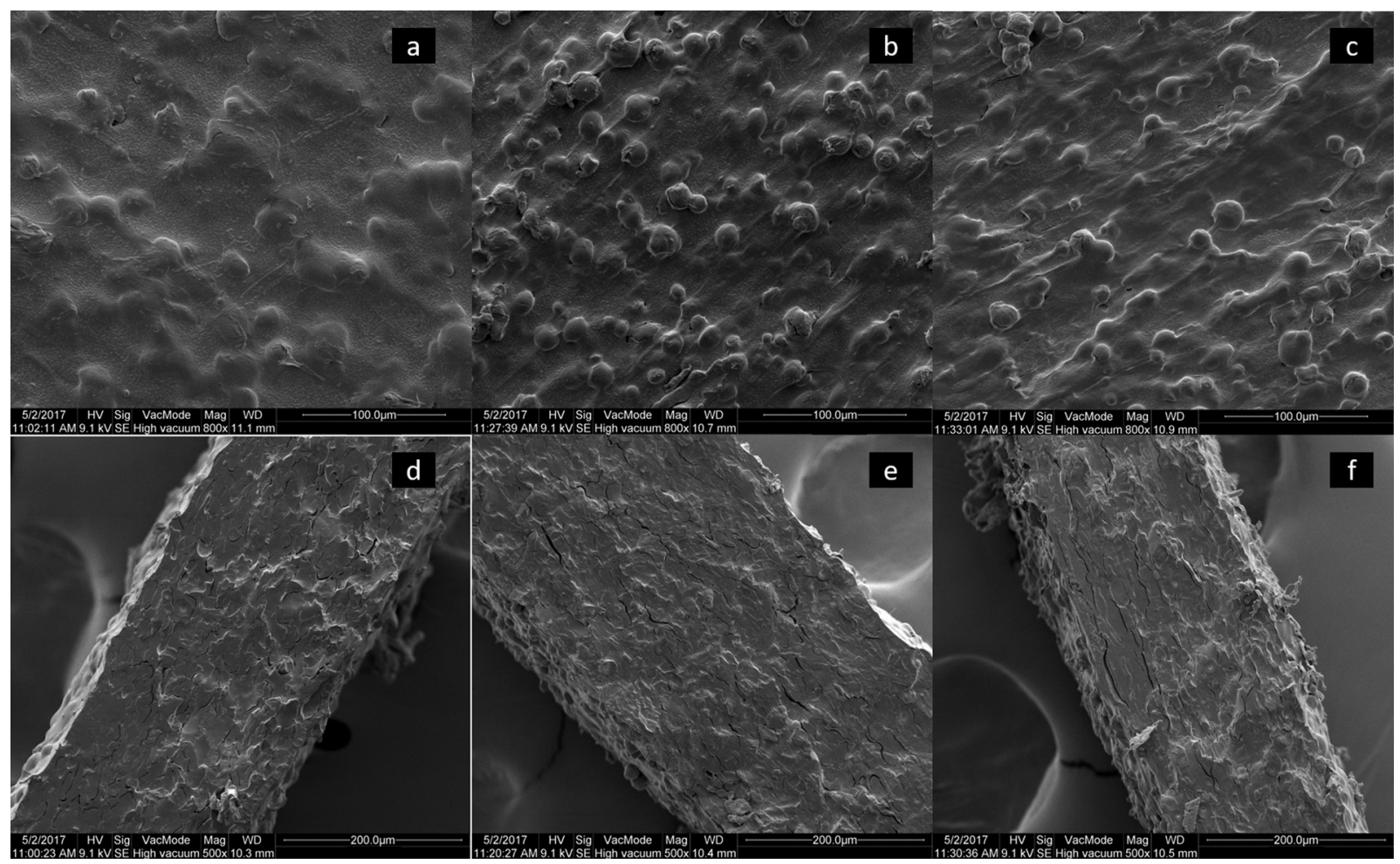

Fig. 5. SEM images of films surface (800x magnification): (a) BF (control film), (b) BFC1 (TPCS/PBAT film with 0.5\%wt of curcumin), (c) BFC2 (TPCS/PBAT film with $0.75 \%$ wt of curcumin) and fragile fracture (500x magnification) (d) BF, (e) BFC1 and (f) BFC2.
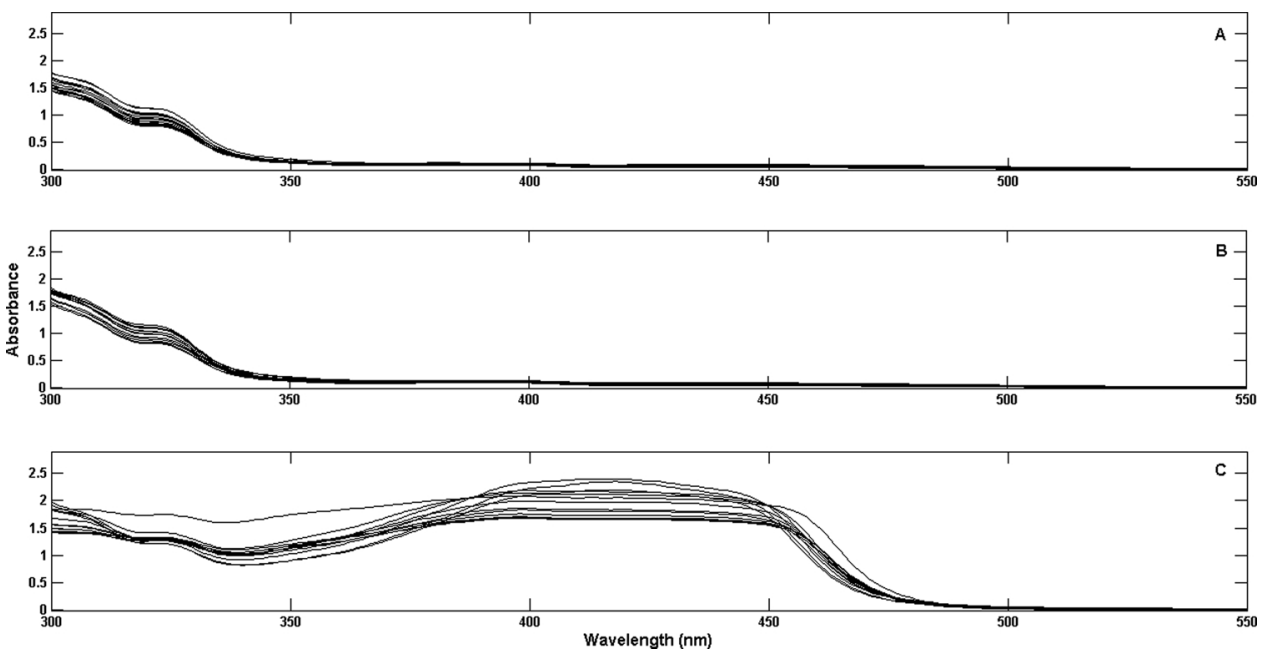

Fig. 6. Chia oil UV-vis spectra under different storage conditions. (a) without protection, (b) TPCS/PBAT control film (BF), (c) TPCS \PBAT film with $0.5 \%$ wt of curcumin (BFC1).

fragmentation and dissolution of starch granules during the extrusion process (Shi et al., 2007).

\subsection{Oxidative stability of packaged chia oil}

The results for accelerated oxidative stability of chia oil packed in the $0.5 \%$ wt curcumin film (BFC1) and the control film (BF) were evaluated from the UV-vis spectra presented in the Fig. 6.

MCR-ALS was applied to resolve the pure spectra and the concentration profiles for three different components in each system. The constraints applied during ALS optimization were spectra and concentration profile non-negativity, and concentration profile closure. The concentration profiles solved for the analyzed chia oil samples are detailed in Fig. 7. From this plot, it was possible to verify the presence of tocopherol and oxidation products and their stability within the assayed days. The spectral profiles (Fig. 8) changed and evolved accordingly over time.

The UV-vis spectra showed the presence of tocopherol (Ixtaina et al., 2011; Souza et al., 2017), of which concentration was lower in chia oil without film protection after one day of the accelerated oxidative stability test. For all cases, tocopherol concentration decreased while the concentration of oxidation products increased within days.

The chia oil protected by the film added with $0.5 \%$ wt of curcumin (BFC1) present lower concentration of the oxidation products throughout the experiment. This result suggests that the film containing curcumin can be an effective active package in the oil protection. 

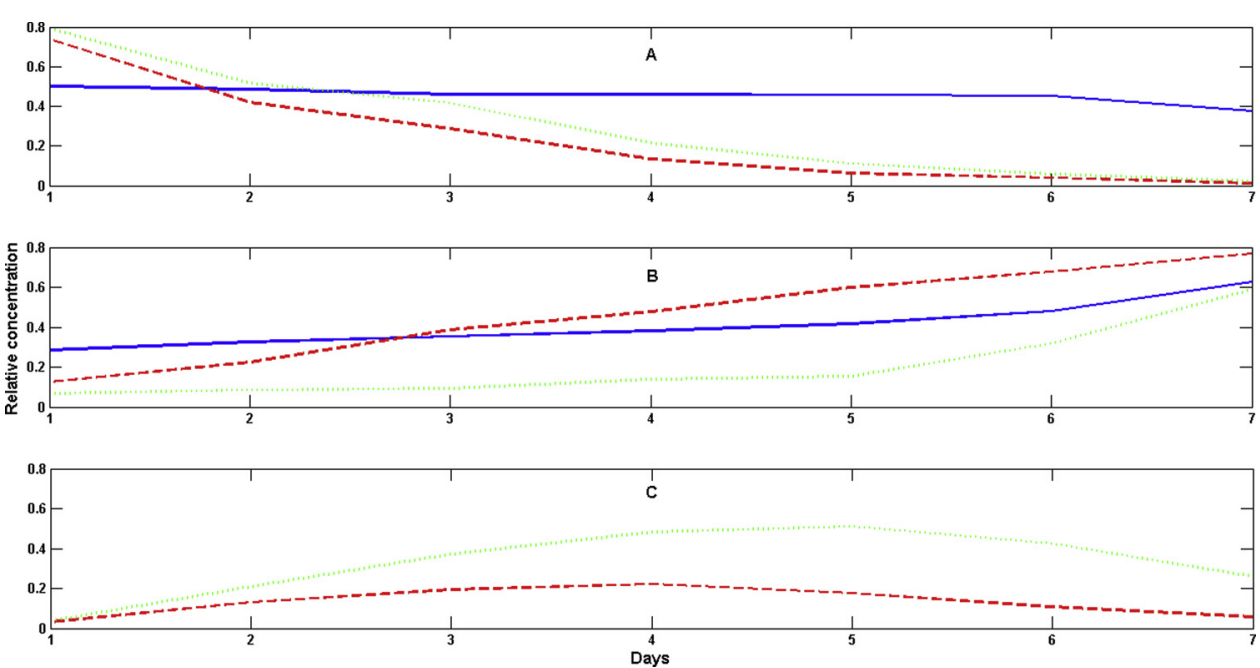

Fig. 7. Relative concentration profiles. (a) tocopherol, (b) oxidation products, (c) films. (-) oil without protection; (-..) oil protected by control film (BF); (...) oil protected by TPCS/ PBAT film with $0.5 \%$ wt of curcumin (BFC1).

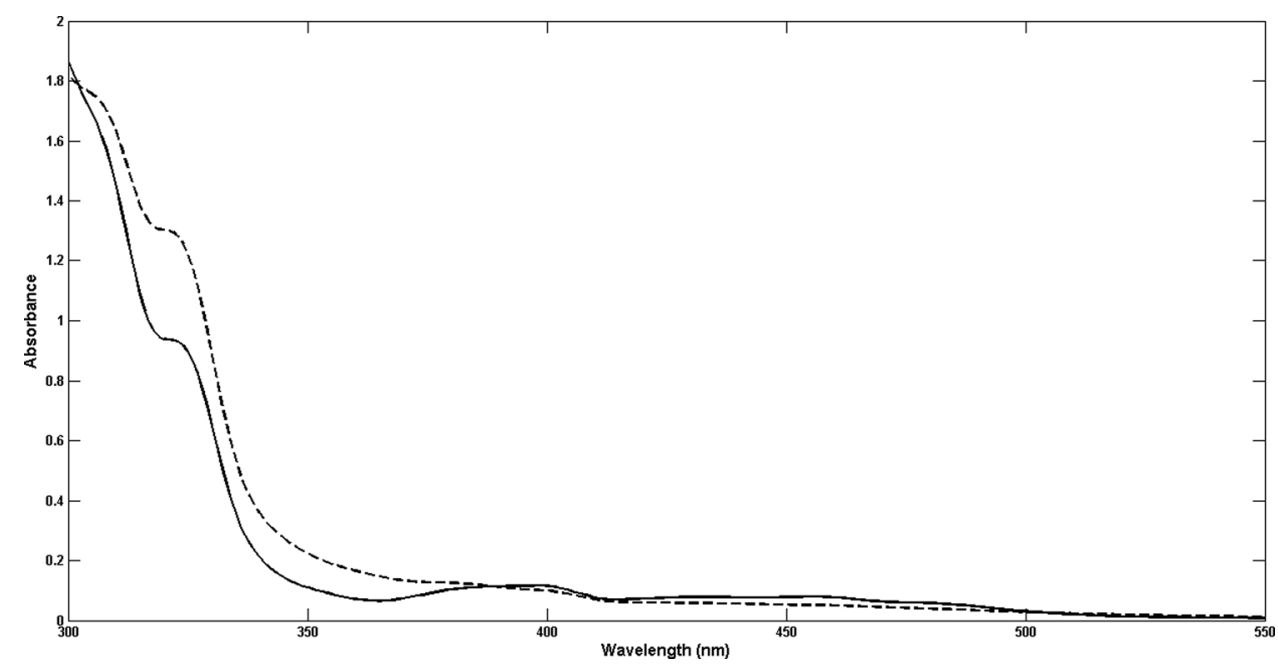

Fig. 8. UV-vis spectra profile recovered by MCR-ALS. (-) oxidation products; (-) tocopherol.

\section{Conclusion}

Curcumin-loaded TPCS/PBAT films were obtained by reactive extrusion. Antimicrobial properties of the films were evaluated against three tested microorganisms (Gram-negative Pseudomonas aeruginosa ATCC 9027, and Escherichia coli AATCC 10536; and Gram-positive bacteria Staphylococcus aureus ATCC 29213). The hydrophilic character of the films increased with the addition of curcumin. Spectroscopic results indicated lower acidic hydrolysis of the glycosidic bonds of starch by the citric acid when curcumin was present. This suggests that curcumin inhibited citric acid action on starch molecules, probably by the competitive role resulting from the association with hydroxyl groups to form hydrogen bonds. Curcumin also inhibited the starch esterification reaction with citric acid. When compared to the control film, TPCS/PBAT film containing $0.75 \%$ wt curcumin presented a slightly lower thermal stability and a significant increase in mechanical parameters (tensile strength, elongation at break, and Young's Modulus), which may be attributed to the lower crosslinking degree of starch in the extrusion process. The film containing curcumin was applied to package chia oil. UV-vis spectroscopy demonstrated that the film was effective to protect the oil against lipid oxidation.

\section{Acknowledgements}

Authors thank to CNPq (Chamada Universal- MCTI/CNPq № 14/
2014, Processo 447768/2014-0), CAPES (Coordenação de Pessoal de Nível Superior Master's scholarship) and Fundação Araucária (Programa Universal/Pesquisa Básica e Aplicada 24/2012, protocolo 7334133700514041013) for the finantial support. This work was financially supported by Associate Laboratory LSRE-LCM (UID/EQU/ 50020/2019) funded by national funds through FCT/MCTES (PIDDAC), and Foundation for Science and Technology (FCT, Portugal). CIMO (UID/AGR/00690/2019) through FEDER under Program PT2020. To the national funding by FCT, P.I., through the institutional scientific employment program-contract for I.P. Fernandes contract.

\section{References}

Andreo, D., \& Jorge, N. (2007). Avaliação da capacidade antioxidante do extrato de gengibre (Gengiber officinale) adicionado ao óleo de soja em teste de estocagem acelerada. Revista Do Instituto Adolfo Lutz, 66(2), 152-157.

Arnao, M., Cano, A., \& Acosta, M. (2001). The hidrophilic and lipophilic contribution to total antioxidant activity. Food Chemistry, 73(2), 239-244.

Baldino, L., Cardea, S., \& Reverchon, E. (2017). Biodegradable membranes loaded with curcumin to be used as engineered independent devices in active packaging. Journal of the Taiwan Institute of Chemical Engineers, 71, 518-526. https://doi.org/10.1016/j. jtice.2016.12.020.

Brandelero, R. P. H., Yamashita, F., \& Grossmann, M. V. E. (2010). The effect of surfactant Tween 80 on the hydrophilicity, water vapor permeation, and the mechanical properties of cassava starch and poly(butylene adipate-co-terephthalate) (PBAT) blend films. Carbohydrate Polymers, 82(4), 1102-1109. https://doi.org/10.1016/j. carbpol.2010.06.034.

da Silva-Buzanello, R. A., de Souza, M. F., de Oliveira, D. A., Bona, E., Leimann, F. V., Cardozo Filho, L., ... Gonçalves, O. H. (2016). Preparation of curcumin-loaded 
nanoparticles and determination of the antioxidant potential of curcumin after encapsulation. Polímeros, 26(3), 207-214. https://doi.org/10.1590/0104-1428.2246.

De Araújo, G. K. P., De Souza, S. J., Da Silva, M. V., Yamashita, F., Gonçalves, O. H., Leimann, F. V., ... Shirai, M. A. (2015). Physical, antimicrobial and antioxidant properties of starch-based film containing ethanolic propolis extract. International Journal of Food Science \& Technology, 50(9), https://doi.org/10.1111/ijfs.12869.

Dilkes-Hoffman, L. S., Pratt, S., Lant, P. A., Levett, I., \& Laycock, B. (2018). Polyhydroxyalkanoate coatings restrict moisture uptake and associated loss of barrier properties of thermoplastic starch films. Journal of Applied Polymer Science, 135(25), https://doi.org/10.1002/app.46379.

Esatbeyoglu, T., Ulbrich, K., Rehberg, C., Rohn, S., \& Rimbach, G. (2015). Thermal stability, antioxidant, and anti-inflammatory activity of curcumin and its degradation product 4-vinyl guaiacol. Food \& Function, 6(3), 887-893. https://doi.org/10.1039/ c4fo00790e.

Garcia, P. S., Eiras Grossmann, M. V., Yamashita, F., Mali, S., Dall'Antonia, L. H., \& Barreto, W. J. (2011). Citric acid as multifunctional agent in blowing films of starch/ PBAT. Quimica Nova, 34(9), 1507-1510. https://doi.org/10.1590/S010040422011000900005.

Garcia, P. S., Grossmann, M. V. E., Shirai, M. A., Lazaretti, M. M., Yamashita, F., Muller, C. M. O., ... Mali, S. (2014). Improving action of citric acid as compatibiliser in starch/polyester blown films. Industrial Crops and Products, 52, 305-312. https://doi. org/10.1016/j.indcrop.2013.11.001.

Gonçalves, R. P., Março, P. H., \& Valderrama, P. (2014). Thermal edible oil evaluation by UV-Vis spectroscopy and chemometrics. Food Chemistry, 163, 83-86. https://doi.org/ 10.1016/j.foodchem.2014.04.109.

González Seligra, P., Eloy Moura, L., Famá, L., Druzian, J. I., \& Goyanes, S. (2016). Influence of incorporation of starch nanoparticles in PBAT/TPS composite films. Polymer International, 65(8), 938-945. https://doi.org/10.1002/pi.5127.

Hraš, A. R., Hadolin, M., Knez, Ž., \& Bauman, D. (2000). Comparison of antioxidative and synergistic effects of rosemary extract with $\alpha$-tocopherol, ascorbyl palmitate and citric acid in sunflower oil. Food Chemistry, 71(2), 229-233. https://doi.org/10.1016/ S0308-8146(00)00161-8.

In, Y. W., Kim, J. J., Kim, H. J., \& Oh, S. W. (2013). Antimicrobial activities of acetic acid, citric acid and lactic acid against Shigella species. Journal of Food Safety, 33(1), 79-85. https://doi.org/10.1111/jfs.12025.

Ishiaku, U. S., Pang, K. W., Lee, W. S., \& Ishak, Z. A. M. (2002). Mechanical properties and enzymic degradation of thermoplastic and granular sago starch filled poly( $\varepsilon$-caprolactone). European Polymer Journal, 38(2), 393-401. https://doi.org/10.1016/S00143057(01)00125-2.

Ixtaina, V. Y., Martínez, M. L., Spotorno, V., Mateo, C. M., Maestri, D. M., Diehl, B. W. K., ... Tomás, M. C. (2011). Characterization of chia seed oils obtained by pressing and solvent extraction. Journal of Food Composition and Analysis, 24(2), 166-174. https:// doi.org/10.1016/j.jfca.2010.08.006.

Jamshidian, M., Tehrany, E. A., Imran, M., Akhtar, M. J., Cleymand, F., \& Desobry, S. (2012). Structural, mechanical and barrier properties of active PLA-antioxidant films. Journal of Food Engineering, 110(3), 380-389. https://doi.org/10.1016/j.jfoodeng. 2011.12.034.

Korodi, T. \& Marcu, N. (1983), Polyurethane microcellular elastomers: 1. Effect of chemical composition on tensile strength and elongation at break of poly(ethylene-butylene adipate) based systems. Polymer, 24, 1321-1326.

Lemes, G. F., Marchiore, N. G., Moreira, T. F. M., Da Silva, T. B. V., Sayer, C., Shirai, M. A., ... Leimann, F. V. (2017). Enzymatically crosslinked gelatin coating added of bioactive nanoparticles and antifungal agent: Effect on the quality of Benitaka grapes. $L W T$ - Food Science and Technology, 84. https://doi.org/10.1016/j.lwt.2017.05.050.

Lendvai, L., Apostolov, A., \& Karger-Kocsis, J. (2017). Characterization of layered silicatereinforced blends of thermoplastic starch (TPS) and poly(butylene adipate-co-terephthalate). Carbohydrate Polymers, 173, 566-572. https://doi.org/10.1016/j. carbpol.2017.05.100.

Liu, X., Wang, Y., Yu, L., Tong, Z., Chen, L., Liu, H., ... Li, X. (2013). Thermal degradation and stability of starch under different processing conditions. Starch/Staerke, 65(1-2), 48-60. https://doi.org/10.1002/star.201200198.
Luo, N., Varaprasad, K., Reddy, G. V. S., Rajulu, A. V., \& Zhang, J. (2012). Preparation and characterization of cellulose/curcumin composite films. RSC Advances, 2(22), 8483-8488. https://doi.org/10.1039/c2ra21465b.

Mensor, L. L., Menezes, F. S., Leitão, G. G., Reis, A. S., Santos, T. C., Coube, C. S., .. Mensor, L. L. (2001). Screening of Brazilian plant extracts for antioxidant activity by the use of DPPH free radical method. Phytotherapy Research, 15(2), 127-130. Retrieved from http://www.ncbi.nlm.nih.gov/pubmed/11268111.

Muller, J., González-Martínez, C., \& Chiralt, A. (2017). Combination of poly(lactic) acid and starch for biodegradable food packaging. Materials, 10(8), 1-22. https://doi.org/ $10.3390 /$ ma10080952.

Musso, Y. S., Salgado, P. R., \& Mauri, A. N. (2017). Smart edible films based on gelatin and curcumin. Food Hydrocolloids, 66, 8-15. https://doi.org/10.1016/j.foodhyd. 2016.11.007.

Nakamura, T., Abe, H., Doi, Y., Kuwabara, K., \& Gan, Z. (2002). Crystalline/amorphous phase structure and molecular mobility of biodegradable poly(butylene adipate-c o -butylene terephthalate) and related polyesters. Biomacromolecules, 3(2), 390-396. https://doi.org/10.1021/bm0156476.

Olivato, J. B., Grossmann, M. V. E., Bilck, A. P., \& Yamashita, F. (2012). Effect of organic acids as additives on the performance of thermoplastic starch / polyester blown films. Carbohydrate Polymers, 90(1), 159-164. https://doi.org/10.1016/j.carbpol.2012.05. 009.

Olivato, J. B., Grossmann, M. V. E., Yamashita, F., Eiras, D., \& Pessan, L. A. (2012). Citric acid and maleic anhydride as compatibilizers in starch/poly(butylene adipate-coterephthalate) blends by one-step reactive extrusion. Carbohydrate Polymers, 87(4), 2614-2618. https://doi.org/10.1016/j.carbpol.2011.11.035.

Olivato, J. B., Marini, J., Yamashita, F., Pollet, E., Grossmann, M. V. E., \& Avérous, L. (2017). Sepiolite as a promising nanoclay for nano-biocomposites based on starch and biodegradable polyester. Materials Science and Engineering C, 70(Part 2), 296-302. https://doi.org/10.1016/j.msec.2016.08.077.

Park, S. I., \& Zhao, Y. (2004). Incorporation of a high concentration of mineral or vitamin into chitosan-based films. Journal of Agricultural and Food Chemistry, 52(7), 1933-1939. https://doi.org/10.1021/jf034612p.

Pizzoli, A. P. D. O., Marchiore, N. G., De Souza, S. J., Santos, P. D., de, F., Gonçalves, O. H., Yamashita, F., .. Leimann, F. V. (2016). Antimicrobial PLA/TPS/gelatin sheets with enzymatically crosslinked surface containing silver nanoparticles. Journal of Applied Polymer Science, 133(8), 43039-43047. https://doi.org/10.1002/app.43039.

Shi, R., Zhang, Z., Liu, Q., Han, Y., Zhang, L., Chen, D., ... Tian, W. (2007). Characterization of citric acid/glycerol co-plasticized thermoplastic starch prepared by melt blending. Carbohydrate Polymers, 69(4), 748-755. https://doi.org/10.1016/j. carbpol.2007.02.010.

Siripatrawan, U., \& Harte, B. R. (2010). Physical properties and antioxidant activity of an active fi $\mathrm{lm}$ from chitosan incorporated with green tea extract. Food Hydrocolloids, 24(8), 770-775. https://doi.org/10.1016/j.foodhyd.2010.04.003.

Souza, M. F., Francisco, C. R. L., Sanchez, J. L., Guimarães-Inácio, A., Valderrama, P., Bona, E., ... Gonçalves, O. H. (2017). Fatty acids profile of chia oil-loaded lipid microparticles. Brazilian Journal of Chemical Engineering, 34(3), https://doi.org/10. 1590/0104-6632.20170343s20150669.

Thaipong, K., Boonprakob, U., Crosby, K., Cisneros-Zevallos, L., \& Hawkins Byrne, D. (2006). Comparison of ABTS, DPPH, FRAP, and ORAC assays for estimating antioxidant activity from guava fruit extracts. Journal of Food Composition and Analysis, 19(6-7), 669-675. https://doi.org/10.1016/j.jfca.2006.01.003.

Valderrama, P., Março, P. H., Locquet, N., Ammari, F., \& Rutledge, D. N. (2011). A procedure to facilitate the choice of the number of factors in multi-way data analysis applied to the natural samples: Application to monitoring the thermal degradation of oils using front-face fluorescence spectroscopy. Chemometrics and Intelligent Laboratory Systems, 106(2), 166-172. https://doi.org/10.1016/j.chemolab.2010.05. 011.

Wu, Y., Chen, Z., Li, X., \& Li, M. (2009). Effect of tea polyphenols on the retrogradation of rice starch. Food Research International, 42(2), 221-225. https://doi.org/10.1016/j. foodres.2008.11.001. 